\title{
A report on characterization of submerged fermentation of Phellinus linteus in Vietnam
}

\author{
Pham Duc Minh', Nguyen Thi Hang ${ }^{2}$, Nguyen Thi Ly ${ }^{3}$, Nguyen Thi Minh Huyen ${ }^{2,3^{*}}$ \\ ${ }^{1}$ Vietnam Military Medical University, 103 Military Hospital, Hanoi, Vietnam \\ ${ }^{1}$ Graduate University of Science and Technology, \\ ${ }^{2}$ Vietnam Academy of Science and Technology, Hanoi, Vietnam \\ ${ }^{3}$ Institute of Biotechnology, Vietnam Academy of Science and Technology, Hanoi, Vietnam
}

(Received: 31/10/2021; Accepted: 23/12/2021)

\begin{abstract}
Phellinus linteus strain GC was cultured for harvesting biomass by submerged fermentation method in $100 \mathrm{~L}$ fermenter which produced in Vietnam. The process of cultivation of this fungus was performed in aerobic conditions with aeration at $1 \mathrm{vvm}$, stirred at $150 \mathrm{rpm}$, temperature from 27 to $29^{\circ} \mathrm{C}$. The observation of cultivation was performed to evaluate the optimum time of growth which produce highest biomass of the mycelium for application purpose of using as functional food. The $\mathrm{pH}$ of medium was slightly changed with decrease then increase again, and reached about 6.0 when cultivation process ends. The biomass of mycelium was gradually increased until about 11 days of cultivation with about $30 \mathrm{~g} / \mathrm{L}$ of dried biomass and the content of of sugar reduced in medium decreased from 40 to $6 \mathrm{~g} / \mathrm{L}$.
\end{abstract}

Keywords: submerged fermentation, Phellinus linteus, biomass, growth progress.

\section{INTRODUCTION}

Submerged fermentation is the process in which growth and decomposition of substrates, is accomplished by microorganisms in the presence of plenty of free water [1]. Submerged fermentation is a good method for producing the biomass of microorganism such as bacteria, yeast and producing many bio products such as beer, wind, yogurt, antibiotic, enzyme, organic acid, etc [2-4]. The application of submerged fermentation in human life was performed since long time ago. From the original, the fermentation mostly by tradition methods, using most of human labor to prepare, incubate, and stir of fermentation materials to get better of fermented process, mixing well of the materials. Later, by the development of technology, the fermentation process can be performed in a big tank with controlling of parameters which affected to the fermentation such as: temperature, $\mathrm{pH}$, aeration, and stir, etc. With this development, the fermentation products were plenty and become popular to the human life. Up to now, not only microorganisms but also the other such as mycelia fungus or even Basidiomycota can be used for submerged fermentation. The advantage of submerged fermentation in this situation is parameters which best suitable for the mycelia to grow were controlled. In which, they help the mycelia to get better growth and produce the desire product for human purposes.

Phellinus linteus is a medicinal mushroom which belong to Basidiomycota and has been known for posed beneficial therapeutic activities in various diseases such as diabetes, tumor, obesity, inflammation, ...[14]. Phellinus linteus polysaccharides have exhibited anticancer activity better than 5-fluorouracil [15]. Extracts of Phellinus linteus decreased cell viability of HCT-116 and SW-480 colon cancer cell line [16]. The potential mechanism may be by suppressing NF- $\kappa \mathrm{B}$ and $\mathrm{Wnt} / \beta$-catenin signaling pathways and inducing oxidative stress [16]. Phellinus linteus polysaccharides could contribute to improving the intestinal barrier function and reversing insulin resistance [17]. 
The culture of Phellinus spp. by submerged fermentation had been performed by Woo-Sik, 2006 showed the culture condition for the mycelia growth such as $\mathrm{C} / \mathrm{N}$ ratio was $10: 1$ to $5: 1$ with $2 \%$ glucose concentration, optimum temperature was $30^{\circ} \mathrm{C}$, etc [5]. Studies of Kim et al. 2000 showed that optimal pH and temperature were around 5.5 and $28^{\circ} \mathrm{C}$ for the Phellinus linteus WI-001 strain growth in cultivation. The $\mathrm{pH}$ value in their experiment was little varied ranging between 5.5 and 6.5 during the whole cultivation period [6]. Liquid cultivation of Basidiomycota such as Phellinus linteus was not performed popularly because of difficulty in understanding the development of the fungal. However, successful in batch cultivation of the Basidiomycota can bring many benefits for human because of the fermentation can act as a small factory to produce as many as possible cell biomass for human requirement, independent from nature production. Liquid fermentation of Inonotus sanghuang for biomass as well as the evaluation of mycochemical contents and antioxidant activities was performed by Tian et. al 2015 [7]. The optimization can make increase in total flavonoids and total phenolics content of mycelia by 37.92 and $77.27 \%$, respectively. The flavonoids and phenolics contribute much to protect human health because of their biological activities such as antioxidant, antibacterial, antifungal, etc. [8-9]. The exo-polysaccharide production in shiitake mushroom submerged fermentation was studied [10]. Other bioactive metabolites also produced by submerged fermentation of edible mushroom Pleurotus ostreatus [11].

In Vietnam, to date, there is no any group study on the liquid fermentation of Phellinus linteus. In this study, the submerged fermentation of Phellinus linteus in fermenter with volume of $100 \mathrm{~L}$ was first performed in Vietnam. The purpose of this study is for collecting the biomass to apply in production of functional food. In experiment, optical density, $\mathrm{pH}$, biomass production and sugar consumption were recorded in 15 days to understand the whole process of liquid fermentation of medicinal mushroom Phellinus linteus. The method had advantage because the easy in control fermentation parameters which can affect to the growth of mycelia than be cultured in the natural environment.

\section{MATERIALS AND METHODS}

\subsection{Research subjects}

Phellinus linteus strain GC used in experiment was obtained from Institute of Biotechnology, Vietnam Academy of Science and Technology (IBT).

\subsection{Materials}

The chemicals were suitable for microbiology research standard. Glucose : Sigma-Aldrich, USA; DNS (3,5-Dinitrosalicylic acid) was obtained from Merck, Germany, etc. The consumable materials such as filter membrane were obtained from Sartorius, Germany; tips: Corning, USA, beakers -: Duran, Germany, etc.

Fermenter (Mitecom, Vietnam), shaking incubator (DaiHan Scientific, Korea). PDA medium for original culture: $200 \mathrm{~g} / \mathrm{L}$ of potato (the potato was slide in cubes, and boiled with water for 20 minutes, the extract was used for making medium), $20 \mathrm{~g} / \mathrm{L}$ of glucose, $20 \mathrm{~g} / \mathrm{L}$ of agar, in $1 \mathrm{~L}$ of water, autoclave for 15 minutes at $121^{\circ} \mathrm{C}$. Cultivation medium: $30 \mathrm{~g} / \mathrm{L}$ of glucose, $15 \mathrm{~g} / \mathrm{L}$ of yeast extract, $0.46 \mathrm{~g} / \mathrm{L}$ of $\mathrm{K}_{2} \mathrm{HPO}_{4}, 1 \mathrm{~g} / \mathrm{L}$ of $\mathrm{KH}_{2} \mathrm{PO}_{4}, 0.5 \mathrm{~g} / \mathrm{L}$ of $\mathrm{MgSO}_{4} .7 \mathrm{H}_{2} \mathrm{O}, 0.01 \mathrm{~g} / \mathrm{L}$ of $\mathrm{FeCl}_{2}, 0.036 \mathrm{~g} / \mathrm{L}$ of $\mathrm{MnCl}_{2} .4 \mathrm{H}_{2} \mathrm{O}, 0.03 \mathrm{~g} / \mathrm{L}$ of $\mathrm{ZnCl}, 0.005 \mathrm{~g} / \mathrm{L}$ of $\mathrm{CuSO}_{4}, \mathrm{pH}$ 6.0. Autoclave for 15 minutes at $121^{\circ} \mathrm{C}$.

\subsection{Methods}

\subsubsection{Fermentation}

Fermentation process was carried out in a fermenter with the volume of $100 \mathrm{~L}$ (Mitecom, Vietnam), is equipped with the temperature control and aeration system. The volume for each culture batch was executed in $65 \mathrm{~L}$, with cultivation conditions: mixing speed $150 \mathrm{rpm}$, temperature $27^{\circ} \mathrm{C}$, aeration level was maintained at $1 \mathrm{vvm}$ of air through a Sartorius membrane $(0.2 \mu \mathrm{m})$ during the fermentation process. Inoculum used was $5 \%$ of working volume. The samples were collected every 24 hours during the cultivation process with about $50 \mathrm{~mL}$. The total cultivation time is observed in 15 days. The cultivation process was repeated three times. Cultivation data was mean value of three time repeat of experiment. 


\subsubsection{Analysis}

pH measurement: $\mathrm{pH}$ was measured by using $\mathrm{pH}$ meter (Daihan Scientific, Korea).

Optical density is measured by the UV-VIS, V-730 Jasco, Japan at OD at $600 \mathrm{~nm}$ or observed by eye.

Biomass content: the culture fluid is filtered through $3 \mathrm{M}$ Whatman filter paper and biomass is collected and dried at $60^{\circ} \mathrm{C}$ until constant weight.

Sugar content: Total reducing sugar during cultivation process is determined by using the Dinitrosalicylic acid (DNS) method [13]. The culture fluid is filtered, and $1 \mathrm{~mL}$ of each filtrate was transferred to a glass test tube, then dilution in $14 \mathrm{~mL}$ of sterile $\mathrm{H}_{2} \mathrm{O}$. The assay mixture contained $1.5 \mathrm{~mL}$ of diluted aliquots and add more $1.5 \mathrm{~mL}$ DNS reagent and heating $\left(90^{\circ} \mathrm{C}\right)$ for ten minutes. The assay mixture was cooled to ambient temperature prior to the addition of $0.5 \mathrm{~mL}$ of $40 \%(\mathrm{w} / \mathrm{v})$ sodium potassium tartrate solution. The absorbance is determined at $540 \mathrm{~nm}$ using Camspec M107 Spectrophotometer (UK). A calibration curve is developed using glucose (100 to $1,000 \mathrm{mg} / \mathrm{L})$ as the standard.

All the analysis experiments were performed in triplicate. Data was analyzed and graphed by using Excel software. Anova single factor was applied for each range of data to determine the multiple range test follow by Duncan's Multiple Range test.

\section{RESULTS AND DISCUSSIONS}

\subsection{Optical density at $600 \mathrm{~nm}$ of Phellinus linteus submerged fermentation}

The values of optical density of Phellinus linteus culture are measured at every time taking sample and were summarized in Figure 1.

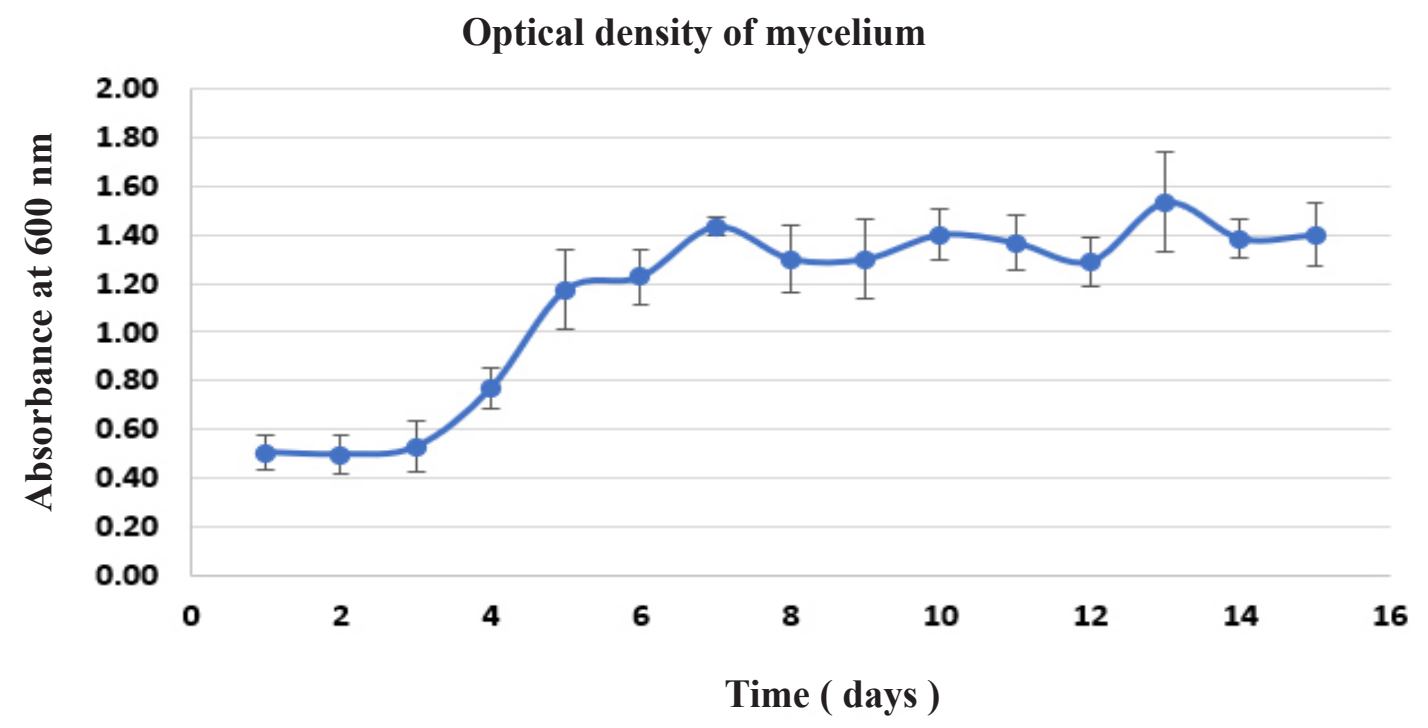

Figure 1. The optical density of mycelium follows to the cultivation time. (Data is mean value \pm standard error of three replicates; Values in the same line with different literal differ at Duncan's multiple range test $(P<0.05))$

In general, the fungal density increased gradually during cultivation time. The density measurement results have a large error, not accurately with amount of the sample because during the mycelium sampling, the heterogeneous size and shape of mycelia make the testing difficult and not accurate; also, the growth curve was not smoothly as expected. The bigger size of mycelia pellets the faster pellet down of mycelia and therefore the solution become clear in a short time, the value of measurement was fluctuated by the time in a decrease manner. However, observations with the naked eye show that, in the fermenter the mushroom biomass increases by the time, the color is gray. The stirring process has made the mycelium stick to the wall and continue to grow; the golden mycelium appeared on the surface of the mycelium which attached to the wall of fermenter. At the end of the cultivation process, the mycelium became high density and mycelium was still adhere to the walls of the fermenter, covering the observing position glass, making it harder to see with naked eyes. 
Although optical density value was not considered much in mycelia development because of the inaccuracy of the measurement, our experiment still showed the increase in the optical density with high fluctuation. Banerjee et al (1993) showed that the optical density of homogenized fungal biomass correlated linearly with the dry weight of the biomass in the samples. And the method was accurate as the conventional dry weight technique but permitted rapid and simple measurement of biomass concentration [12]. However, the homogenized fungal biomass for the Basidiomyces was really difficult to obtain in cultivation. Lucky that our experiment results made sense even it has high fluctuation in measurement. Therefore, temporary method measure OD can be used which rapid evaluation of development of the mycelia of Basidiomyces in the time of waiting for dried biomass results.

\section{2. $\mathrm{pH}$ value variable during cultivation process}

$\mathrm{pH}$ value of culture fluid during cultivation process was recorded for each 24 hours during 15 days. $\mathrm{pH}$ value changes over time. Initial $\mathrm{pH}$ was 5.2 and during the first seven days, the $\mathrm{pH}$ gradually decreases to 4.2. Then gradually increase again until harvest, reach nearly 6.0. The $\mathrm{pH}$ change during the growth time of mycelium may cause by the uptake and metabolism of media components. Several days near the harvest time, the mycelium changes color, become darker. The change of $\mathrm{pH}$ value was shown in Figure 2 below.

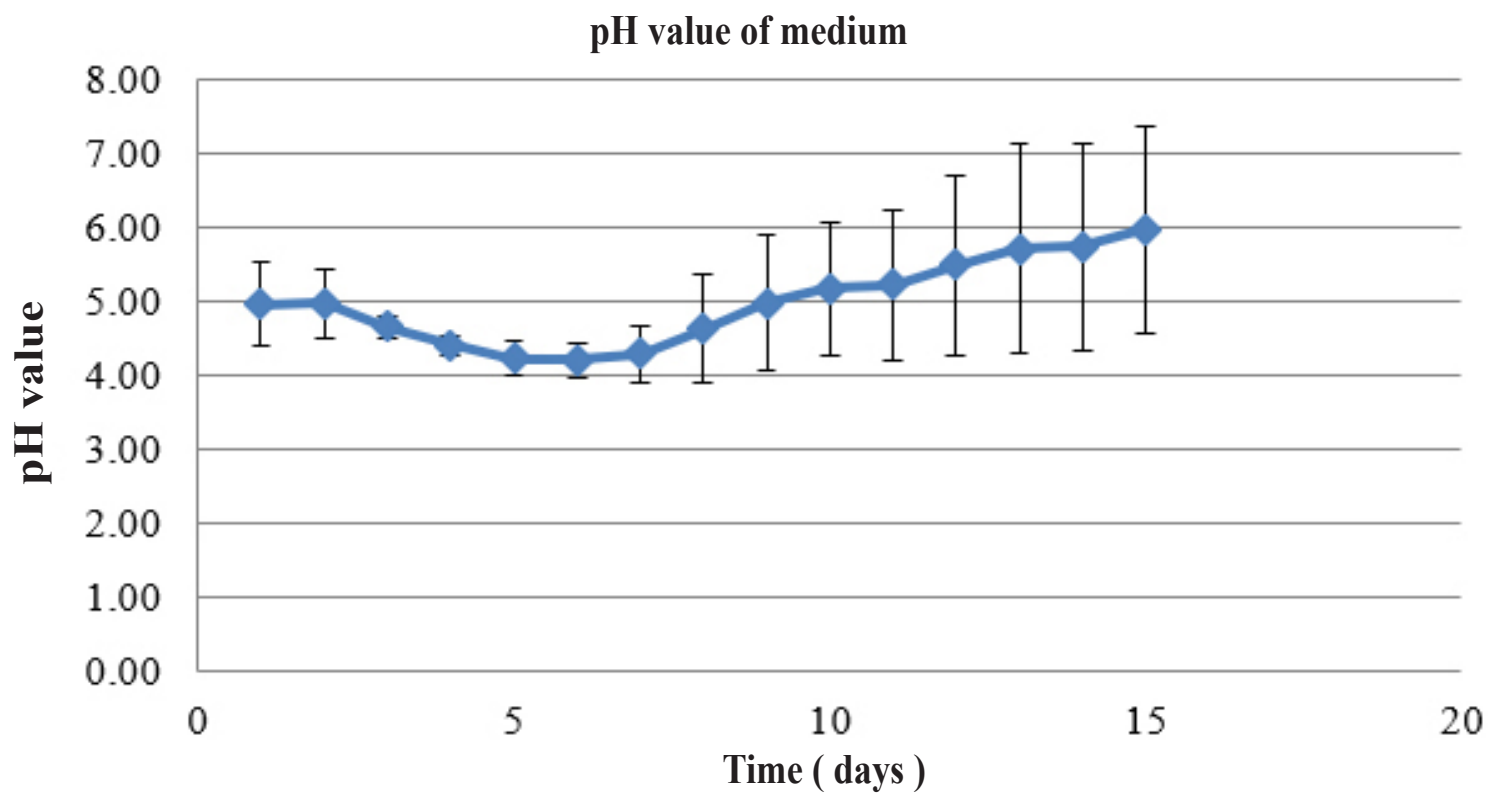

Figure 2. The $p H$ value of culture fluid follows to the cultivation time.

(Data is mean value \pm standard error of three replicates; Values in the same line with different literal differ at Duncan's multiple range test $(P<0.05))$

The $\mathrm{pH}$ value in the experiment was ranged from 4.2 to 6.0 during period of fermentation. Our results obtained were not so much different with Kim et al (2000) results in which the pH value ranging between 5.5 and 6.5 [6]. The change in $\mathrm{pH}$ value may result from the change of medium components by the metabolism of mycelium to develop their biomass. Different strain of PL may cause little different in $\mathrm{pH}$ of media but they are common growth better when medium toward slightly acidic condition [18].

\subsection{Dry biomass of Phellinus linteus submerged fermentation}

Dried biomass content was also evaluated over time in during 15 days of cultivation. Initially, the amount of biomass was low and gradually increased; the maximum amount was got at 8 to 11 days with the average about $30 \mathrm{~g} / \mathrm{L}$ of dried biomass. After 11 days the biomass did not increase further; the color of cultivation fluid becomes darker, smell of fluid also developed greater. The measured data after determining dried biomass is shown in the Figure 3. 


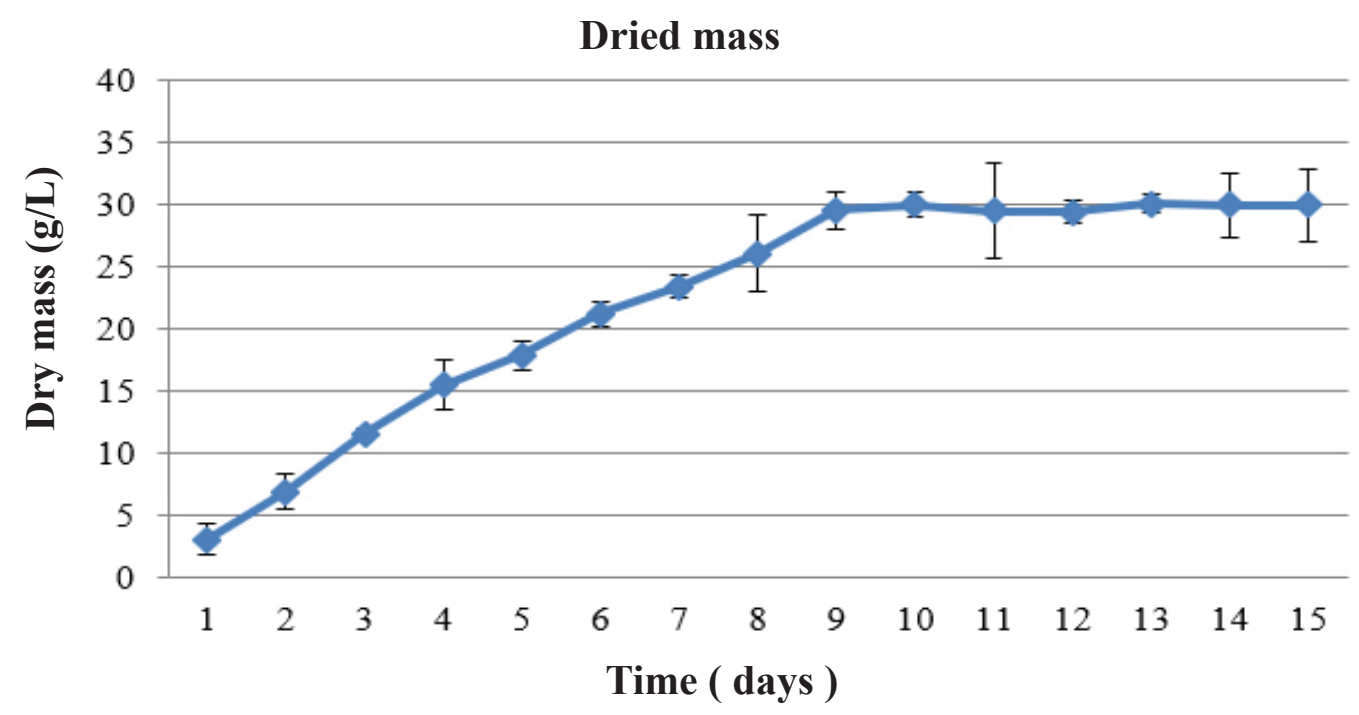

Figure 3. The mycelium biomass follows to the cultivation time.

(Data is mean value \pm standard error of three replicates; Values in the same line with different literal differ at Duncan's multiple range test $(P<0.05))$

From the experiment, we found that even mycelia still consumed sugar for development but the biomass of the mycelia did not increase much after 11 days. Thus, for the purpose of collection of highest biomasses with time, the cultivation time can be stopped at after 11 days. However, if continue cultivation would be increased the bioactive compounds of the mycelia the fermentation can be continued further but the evaluation method for that compound should be performed along with the fermentation. For example, Kim et al, culture for high density fermentation of Phellinus linteus WI-001 in which WI-001 was producer of polysaccharides with potent anticancer activities [6]. The Inonotus sanghuang was also fermented for mycelial production and determined the effects of cultivation method on the yield of total flavonoids, total phenolics, polysaccharides as well as the antioxidant activities of mycelial extracts [7]. Or Lentinus edodes (shiitake mushroom) was optimized for mycelial growth and exo-polysaccharide production [10]; edible mushroom Pleurotus ostreatus was fermented for production of bioactive metabolites such as fatty acids, phenolic metabolites, nucleotides and alkaloids [11].

\subsection{Reducing sugar content during the growth process of mycelium}

The reducing sugars were calculated using standard curve which plotted by sugar as standard material. The graph of reducing sugar in correlation with time of fermentation in Figure 4 was shown below.

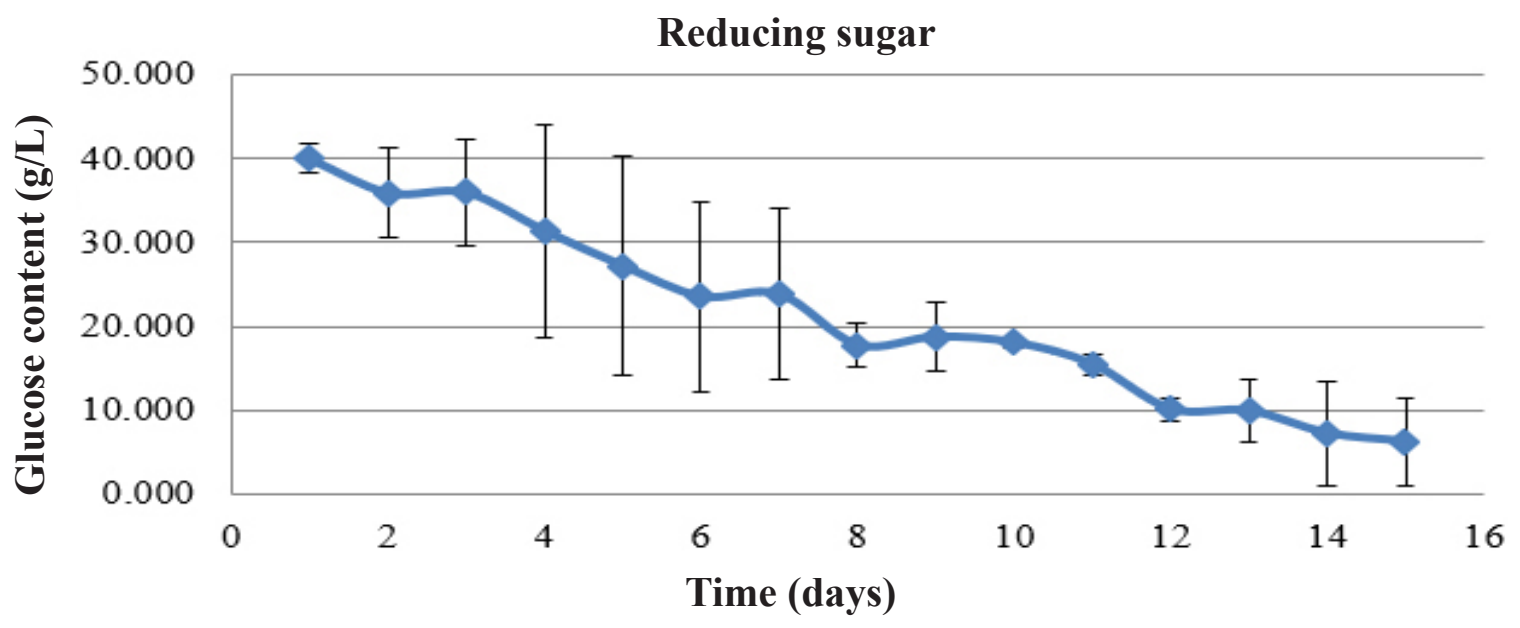

Figure 4. The reducing sugar content of the culture fluid follow to cultivation time.

(Data is mean value \pm standard error of three replicates; Values in the same line with different literal differ at Duncan's multiple range test $(P<0.05))$ 
During the 15 days of observation, the sugar content has decreased from $40 \mathrm{~g} / \mathrm{L}$ to about $6 \mathrm{~g} / \mathrm{L}$. This shows that the fungal biomass used sugar in the culture to develop their construction. Thus, within 15 days, the sugar content has decreased significantly. The cultivation can stoped to create a new fermentation cycle at this moment or to recover the biomass due to the depletion of nutrients in the culture. In this experiment, the data had high deviation in the days from four to seven days. This high deviation may come from the error of different batch of each time of experiment. The total experiment time of one repeat took about two months since the start cultivation from the agar plate to the each liquid cultivation of upper levels of fermentation $(100 \mathrm{~mL}, 1 \mathrm{~L}, 5 \mathrm{~L}$ and $100 \mathrm{~L})$. Therefore, different of amount of mycelia in start cultivation may result in bigger different in the larger cultivation. Furthermore, the experience of the person who performed the experiment is also very importance. If during experiment process, the performer did not consistently take samples may also result in big error of experiment. This result was three times repeats of experiment with unexpected deviation in that way. Further repeatation may reduce the error range in experiment data. However, in total with this data, the trend of reduce of sugar was clearly observed. Similar observation in Kim et. al. (2000), the sugar content was reduced in their experiment from about 21 to $0.5 \mathrm{~g} / \mathrm{L}$ in seven days. The reduction of sugar was faster than our experiment may be because of different in start concentration of sugar. They recorded that high initial glucose concentration enhanced biomass production but showed negative effect on specific growth rate [6].

\subsection{The growth dynamics of Phellinus linteus in submerged fermentation}

Summarizing the above results for clearly observation of trend of mycelial growth in liquid medium was showed in Figure 5. Within 15 days of cultivation in $100 \mathrm{~L}$ fermentor with $65 \mathrm{~L}$ of medium volume, stirring speed $150 \mathrm{rpm}$, aeration $1 \mathrm{vvm}$, the temperature was adjusted in the range $27-28^{\circ} \mathrm{C}$, the highest biomass yield was about $30 \mathrm{~g} / \mathrm{L}$ and $\mathrm{pH}$ of medium ranging from 4.2 to 6 . Biomass production increased during the first ten days and thereafter did not increase further, but remained in equilibrium. In the result of Yi-Li Feng group (2010) whom studied kinetic model of mycelial growth of Lintinus ododes (shiitake mushroom), the biomass increased in first 120 hours (about five days) of cultivation time and reached equillibrium after that [10]. The different in experiment conditions and mycelial strain make different between our result and their result. Meanwhile, the glucose content continued to decrease until the end of the cultivation process. Thus the glucose concentration in medium reduced during the increase of mycelial biomass. After nine days, the biomass of fungus did not much increase but sugar continued to decrease may because of the fungus still needed nutrition for maintaining the survival but in other concentration to the metabolism of their substance inside the mycelium.

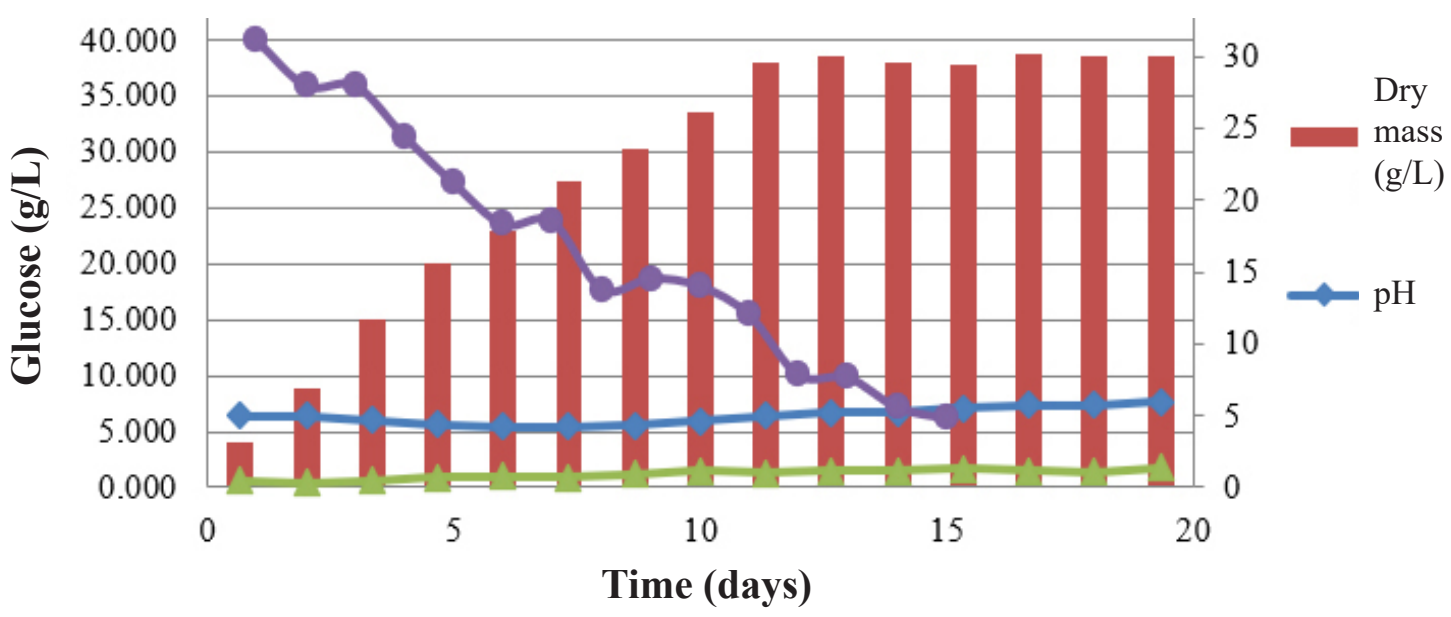

Figure 5. Combination graph of the mycelium growth process with factors: pH, OD, dried mass, sugar 


\section{CONCLUSION}

The submerged fermentation of Basidiomyces was performed for Phellinus linteus in this experiment. The mycelia biomass was gradually increased to maximum of about $30 \mathrm{~g} / \mathrm{L}$ of dried biomass. The sugar consumption decreased from $40 \mathrm{~g} / \mathrm{L}$ to about $6 \mathrm{~g} / \mathrm{L}$. $\mathrm{pH}$ value was ranging between 4.2 to 6.0 even initial $\mathrm{pH}$ was 5.2. Depend on the purpose of using biomass, the cultivation can be stopped after 11 days or continued further. This experiment was the first evaluation of fermentation of Phellinus linteus in Vietnam.

\section{REFERENCES}

[1]. S. I. Mussatto and J. A. Teixeira, "Lignocellulose as raw material in fermentation processes," Current, Research, Technology and Education Topics in Applied Microbiology and Microbial Biotechnology, Microbiology book series, vol. 2, no. 2, pp 897-906, 2010.

[2]. D. Wesenberg, I. Kyriakides, and S. N. Agathos, "White-rot fungi and their enzyme for the treatment of industrial dye effluents," Biotechnology Advances, vol. 22, no. 1-2, pp. 161-187, 2003.

[3]. H. D. Martin, S. Kock, R. Scherrers, K. Lutter, T. Wagener, C. Hundsdorfer, S. Frixel, K. Schaper, H. Ernst, W. Schrader, H. Gorner, and W.Stahl, "3,3'- Dihydroxyisorenieratene, a natural carotenoid with superior antioxidant and photoprotective properties," Angewandte Chemie (International ed in English), vol. 48, no. 2, pp. 400-403, 2009.

[4]. S. A. Mapari, U. Thrane, and A. S. Meyer, "Fungal polyketide azaphilone pigments as future natural food colorants?," Trends Biotechnology, vol.28, no. 6, pp. 300-307, 2010.

[5]. W-S. Jo , Y-H. Rew, S-G. Choi, G-S. Seo, J-M. Sung, J-Y. Uhm, "The Culture Conditions for the Mycelial Growth of Phellinus spp.," Myobiology, vol. 34, no. 4, pp 200-205, 2006.

[6]. J.-L. Kim, H.-K. Kwon, G.-T- Chun, and K.-J. Kim, "Studies on cultural characteristics for high density fermentation of Phellinus linteus WI-001", Korean Journal of Applied Microbiology and Biotechnology, vol. 28, no. 2, pp. 105-110, 2000.

[7]. X-M. Tian, Y-C. Dai, A-R. Song, K. Xu, and L-T. Ng, "Optimization of liquid fermentation medium for production of inonotus sanghuang (higher basidiomycetes) mycelia and evaluation of their mycochemical contents and antioxidant activities", International Journal of Medicinal Mushrooms, vol. 17, no. 7, pp. 681-691, 2015.

[8]. A. Ghasemzadeh and N. Ghasemzadeh, "Flavonoids and phenolic acids: Role and biochemical activity in plants and human," Journal of Medicinal Plants Research, vol. 5, no. 31, pp. 6697-6703, 2011.

[9]. S. Kumar and A. K. Pandey, "Chemistry and biological activities of flavonoids: an overview, "Scientific World Journal, vol. 2013, pp. 62750, 2013.

[10]. Y-L.Feng, W-Q. Li, X-Q. Wu, J-W. Cheng, and S-Y. Ma, "Statistical optimization of media for mycelial growth and exo-polysaccharide production by Lentinus edodes and a kinetic model study of two growth morphologies," Biochemical Engineering Journal, vol. 49, no. 1, pp.104-112, 2010.

[11]. L-M. Papaspyridi, N. Aligiannis, E. Topakas, P. Christakopoulos, A-L Skaltsounis and N. Fokialakis, "Submerged Fermentation of the Edible Mushroom Pleurotus ostreatus in a Batch Stirred Tank Bioreactor as a Promising Alternative for the Effective Production of Bioactive Metabolites," Molecules, vol. 17, no. 3, pp. 2714-2724, 2012.

[12]. U. C. Banerjee, Y. Chisti, and M. Moo-Young, "Spectrophotometric determination of mycelial biomass," Biotechnology Techniques, vol. 7, pp. 313-316, 1993.

[13]. W. W. Luchsinger, R. A. Cornesky, "Reducing power by the dinitrosalicylic acid method," Analytical Biochemistry, vol. 4, pp. 346-7, 1962. 
[14]. R. Khursheed, S. K. Singh, S. Wadhwa, and M. Glati, "Therapeutic potential of mushrooms in diabetes mellitus: Role of polysaccharides," International Journal of Biological Macromolecules, vol. 164, pp. 1194-1205, 2020.

[15]. T. Khan, A. Date, H. Chawda, K. Patel, "Polysaccharides as potential anticancer agents-A review of their progress," Carbohydrate Polymers, vol. 210, pp 412-428, 2019.

[16]. D. S. Seklic, M. Stankovic, M .G. Milutinovic, and M. D. Topuzovic, "Cytotoxic, antimigratory, pro-and antioxidative activities of extracts from medicinal mushrooms on colon cancer cell lines," Archives of Biological Sciences, vol. 68, no. 1, pp. 93-105, 2016.

[17]. Y. Liu, C. Wang, J. Li, T. Li, Y. Zhang, Y. Liang, and Y. Mei , "Phellinus linteus polysaccharide extract improves insulin resistance by regulating gut microbiota composition," FASEB Journal: official publication of the Feredation of the American Societies of Experimental Biology", vol. 34, no. 1, pp. 1065-1078, 2020.

[18]. Tran Thi Hien et al., "Effect of medium conditions to Phellinus linteus growth in submerged culture," Journal of Science and Technology, Ministry of Industry and Trade of the Socialist Republic of Vietnam, vol. 42, pp. 20-23, 2020.

\title{
Nghiên cứu dặc điểm lên men chim của Phellinus linteus ở Việt Nam
}

\author{
Phạm Đức Minh¹, Nguyễn Thị Hằng², Nguyễn Thị Lý ${ }^{3}$, Nguyễn Thị Minh Huyền ${ }^{2,3}$ \\ ${ }^{1}$ Học viện Quân y, Bệnh viện Quân y 103, Hà Nội, Việt Nam \\ ${ }^{2} Đ a i$ hoc Khoa hoc và Công nghẹ, \\ Viện Hàn lâm Khoa họ và Công nghệ Việt Nam, Hà Nội, Việt Nam \\ ${ }^{3}$ Viện Công nghệ Sinh hoc, Viện Hàn lâm Khoa học và Công nghệ Việt Nam, Hà Nội, Việt Nam
}

\section{Tóm tắt}

Chủng Phellinus linteus GC được nhân nuôi để thu sinh khối bằng phương pháp lên men chìm trong thùng lên men $100 \mathrm{~L}$ được sản xuất tại Việt Nam. Quá trình lên men nấm được sục khí ở tốc độ 1 vvm, khuấy ở tốc độ 150 vòng/phút, nhiệt độ lên men được duy trì ở $27 \div 29^{\circ} \mathrm{C}$. Việc quan sát quá trình lên men được thực hiện nhằm đánh giá thời gian sinh trưởng tối ưu để tạo ra sinh khối cao nhất của sợi nấm, ứng dụng trong sản xuất các dạng thực phẩm chức năng từ sinh khối nấm. Độ $\mathrm{pH}$ của môi trường dao động và đạt khoảng 6,0 khi quá trình lên men kết thúc. Sinh khối của sợi nấm được tăng dần cho đến khoảng 11 ngày lên men và đạt khoảng $30 \mathrm{~g} / \mathrm{L}$ sinh khối khô đồng thời với quá trình giảm lượng đường trong môi trường từ $40 \mathrm{~g} / \mathrm{L}$ xuống khoảng $6 \mathrm{~g} / \mathrm{L}$.

Tù khóa: lên men chìm, Phellinus linteus, sinh khối, quá trình sinh trương. 